\title{
The relationship between marital status and employment in South Africa
}

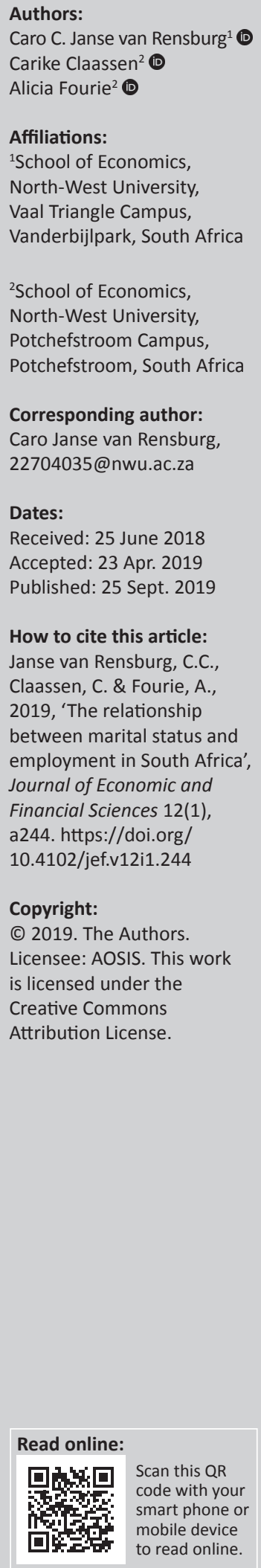

Orientation: Marriage formalises gender roles in society and as such has a significant impact on the labour force. The institution does, however, change over time, which makes it important to continually assess the impact that it has.

Research purpose: In this article, the impact of marital status on employment is gauged.

Motivation for the study: Marriage is arguably one of the most engrained institutions in modern society. Understanding the link between the marriage institution and employment could be essential in understanding the social and economic externalities that policy could have.

Research design, approach and method: Logistic regressions are used to analyse what the relationship between different marital statuses and employment is.

Main findings: The findings show that women are least likely to be employed when they are married, whereas men are most likely to be employed when they are married.

Practical/managerial implications: Marriage clearly influences the labour market outcomes of women differently than those of men. This is an important certitude, especially for policymakers who have to consider how their policies will differently affect men and women, and thereby how those policies will either work against or for gender equality.

Contribution/value-add: This article attempts to uncover the link between marital status and employment in South Africa and thereby realise the potential implications of changes in marriage patterns on employment patterns.

Keywords: employment; gender; labour; marital status; logistic regression.

\section{Introduction}

Marriage as an institution has witnessed large changes in the recent past, and South Africa is no exception to this. An article by Palamuleni (2010) shows a decrease in the percentage of women married in South Africa from 35\% in 1996 to 30\% in 2001. Various other studies on this contraction of the marital institution were conducted in the South African case (see, e.g., studies by Moore \& Govender 2013; Posel \& Casale 2009; Posel, Rudwick \& Casale 2011; Posel \& Casale 2013; Posel \& Rudwick 2013). These studies provide much insight into the reason for this decreasing trend in marital status, but very little to no analysis of the impact that this trend will have on other economic outcomes (such as employment trends) is provided. It is here that this article aims to make its contribution, by analysing the impact that marital status can have on employment trends.

Along with this decrease in marriage rates, there has been a trend towards greater female labour force participation and employment has increased across the world, including in the developing world. This can be seen in the studies by Coleman and Pencavel (1993), Mehra and Gammage (1999) and Wamboye, Adekola and Sergi (2015), where it was found that women's employment is increasing over time. Despite the fact that women had higher employment levels, they were more likely to be retained in less desirable employment that required more working hours for lower wages. These working conditions should also be considered when investigating the employment of women, especially when focusing on marriage rates, as it lowers the incentive for women to enter the labour market if they know that the employment opportunities available to them are not as good as what their husband's opportunities are. Studies concerning the labour supply of women often involve the inclusion of a marital status or rate variable because of the important role it plays in influencing women's behaviour and outcomes in the labour market (Hamid 1991; Muller \& Posel 2008; Ntuli 2007a, 2007b; Yakubu 2010). 
Women tend play a prominent role in a country's economy, which is evident in the multitude of research, suggesting that greater gender inequality results in lower GDP growth (Agenor \& Canuto 2015; Dollar \& Gatti 1999; Forbes 2000; Klasen 1999; Klasen \& Lamanna 2009; Seguino 2000). This research shows that there is a negative relationship between growth and inequality. So even if one does not deem it to be important from a developmental perspective to consider the principled injustices women face because of gender inequality, it is worth noting that this inequality is to the detriment of the economy as a whole.

Within this global context of changes in marriage trends, the South African gender landscape is unique. It is not just distinctive in terms of other foreign countries, but even on the African continent (Hosegood, McGrath \& Moultrie 2009). Because of distinct historical discrimination that was institutionalised in South Africa, there are significant detriments to women. To a large extent, the political and the cultural differences in the marriage institution are what set South Africa apart in studies on marriage. Those effects, along with the costs of paying a bride wealth (ilobolo), by certain groups, and the costs of supporting a family, prove to be great barriers to entry into matrimony (Casale \& Posel 2013; Casale, Posel \& Rudwick 2011; Mkhizwe 2006; Posel \& Rudwick 2013; Posel \& Rudwick 2015). Therefore, the decrease in the South African nuptiality has been higher than in most other African countries (Hosegood et al. 2009).

\section{Literature review}

The section starts off discussing past international studies that utilise the theories mentioned above, to gain a better and broader understanding of labour supply characteristics around the world. The second part then focuses on studies that investigate how individual characteristics influence labour supply in South Africa. Women in South Africa are less likely to enter the labour market, and when they do, they are less likely to be employed (Barker 2015). For this reason, the interaction of supply and demand needs to be considered. The final part of this literature review will therefore specifically look at studies that have analysed employment in the context of the individual characteristics of labour supply in South Africa.

\section{International perspectives}

Human capital theory shows that those skills that are accumulated through experience increase the probability that one would participate in the labour force (Becker 1993). Collet and Legros (2016) use education level as a proxy for potential wages because potential wages for the unemployed are not available in survey data. This illustrates that potential wages could be the mechanism through which education influences the decision to participate in the workforce.

Education may serve as a proxy for potential income, but this does not include non-labour income. Non-labour income is, however, a relevant consideration for women who have to decide whether or not to participate in the labour force (Collet \& Legros 2016). This is because the non-labour income could serve as a substitute for a wage, which reduces the incentive to work. Non-labour income could deter women from entering the labour force because a higher non-labour income reduces the need for other incomes. Capital income is one source of non-labour income that has been used (Hardoy \& Schone 2015), but there are many other sources that can also be considered, such as social grants.

When investigating female labour force participation, children are often included because it is common in most cultures that the woman has the responsibility to take care of the children (Chen et al. 2014). It is therefore argued that children take up the time that women could have otherwise used to participate in the labour force (Bredemeier \& Juessen 2013; Collet \& Legros 2016). Therefore, childcare and other familial responsibilities can be considered as the opportunity cost of labour participation for women (Borck 2014).

Age is yet another variable that is widely accepted as a driver behind labour participation (Barker 2015; Chen et al. 2014). This is because of age being viewed as an indicator of the skills, knowledge and experience that was accumulated over those years. Collet and Legros (2016) referred to age as a proxy for the marketability of women, which then reflects those skills, knowledge and experience. This does, however, come with considerable complexities especially when considering the age of that woman's children. After the age of 50 , age also tended to have an opposing effect on woman's willingness to enter the labour market (Collet \& Legros 2016).

The husband's work is also a variable that is often considered when analysing women in the labour market (Berger, Islam \& Liegeois 2011; Chen et al. 2014). This is something that can obviously only be measured if the woman is married. Because unmarried women are to be considered in this article, it would make sense to see marriage as a proxy for the income of husbands.

\section{Employment in South Africa}

Kingdon and Knight (2004) studied the dynamics of the entry into and duration of unemployment in South Africa. What they found was that men were $19.1 \%$ less likely to voluntarily enter into unemployment from employment than women were, but they were $11.3 \%$ more likely to do so. It was also found that married individuals had a 6.4 percentage point greater probability of entering into unemployment from employment than unmarried individuals. This highlights the expectation that such a link between marital status is expected, and subsequently found, although the article does little to analyse that link, as it was not necessary within the scope of their article.

The empirical approach of the Kingdon and Knight (2004) study is also quite useful. In their study, a demand-side variable (entry into unemployment) was used as the 
dependant and supply-side individual characteristics were used as controls, which indicates the usefulness of looking at this interaction between supply and demand.

Another study that looked at the interaction of demand and supply by analysing employment through the lens of personal productive characteristics was one done by Burger and Jafta (2006). They calculated an employment gap using the Blinder-Oaxaca (BO) decomposition method, which is ordinarily used to decompose wage gaps. The BO was adapted for binary variables and used to decompose the race employment gap into a section described by individual characteristics and a section not described by those characteristics. This latter section is assumed to partly illustrate any possible discrimination in the labour market.

\section{Theoretical overview}

In this section, the theoretical underpinnings of the study are discussed. Firstly, theory surrounding labour supply will be uncovered. Here the theoretical determinants of a person's willingness to participate in the labour force are considered. Secondly, labour demand theory will be discussed to show the other side of the labour coin. The final section looks at the household and specifically at marriage and its influence on the labour force. Here the theoretical link is made between the labour market and the marriage market.

\section{Labour demand theory}

Much of the theory of labour demand is preoccupied with the amount of employment that is demanded by the employers, but is not as concerned by what type of employment is demanded (Barker 2015). This means that there is no generalised theory that explains the individual characteristics that are sought by employers. For a study that looks at those individual characteristics, theory has to be salvaged from a variety of places and conglomerated to be able to build a theoretically sound model.

This endeavour has resulted in the realisation that there are a few trends in the labour market, which serve as a theoretical basis of what to expect when studying employment or unemployment. Some insights on employment and unemployment are provided by Barker (2015), Bhorat (2003), Burger and Jafta (2006), Dias and Posel (2007) and Kingdon and Knight (2004). An example is that education is valued in the labour market, which is evident from the increasing decline of unskilled employment relative to skilled employment (Barker 2015). There may be some debate surrounding the relative importance of different types of education or how important it is, but there are not many studies that attempt to entirely disprove the value of education.

\section{Marriage-specific theory}

In 'A Theory of the Allocation of Time', Becker (1965) hypothesised about the allocation of time within a household. In this model, the household is set to be the same as a small firm. The household then is assumed to produce commodities by using time and other goods. Households typically face budget constraints and time constraints, which limit their ability to increase utility. Income is then spent either by buying goods, or by giving up income for other purposes (Becker 1965). This implies that households will have to make decisions regarding who works in the labour market and for how much.

These types of decision mean that it is important to consider a person's human capital because of how it will impact the household's income (Becker, 1965). If, for example, the household perceives the woman's chances of being employed to be less and her potential income to also be less, the household may make a collective decision that the woman should rather spend her time tending to household matters rather than attempt to acquire more income. It logically follows that unmarried individuals should make their decisions based solely on the individual's potential income and not the collective, resulting in a greater likelihood of participating in the labour force.

The implication for this article is that because the total household income is important to consider, it means that the husband's income has an impact on whether a woman would enter the labour force. The higher the income of the husband in a household is, the more valuable the time of the wife would be, resulting in her rather not entering the labour force. In this study, both married and unmarried people will be considered and therefore considering the spouse's income, for the unmarried, would not be possible. The marital status itself will serve as a proxy for receiving an income from the husband.

Grossbard-Schechtman and Neuman (1988) further develop the theory of the allocation of time by including the interaction of the characteristics between both parties in the marriage and looking at how that influences women's labour supply. They found that the husband's characteristics are positively related to the wife's labour supply. Women who have specific characteristics, such as being younger, are valued in the marriage market, but are less attractive in the labour force. This study shows that it can be expected that married women are less likely to enter the labour market. The study conducted by Grossbard-Schechtman and Neuman (1988) further gives an indication of the type of variables that need to be included when looking at the labour supply of women and how that is affected by the marital status. This is said to work through a mechanism of compensating differentials, which basically means that the higher the woman's traits are valued, in the marriage market, the more the husband has to compensate for those traits by providing her with a larger share of the income. The more valued a women's characteristics are, the more likely it is that her 'needs' will be satisfied in the marriage and she will therefore be less likely to participate in the labour force. Therefore, characteristics, such as age and education, that 
play a role in both the marriage market and the labour market, need to be considered.

The theory on marriage suggests that marriage is a deterrent to gender equality in the labour market. This is because of marriage discouraging investment in human capital and because of compensating differentials that provide further disincentive to enter the labour market. The theory does, however, assume marital status to be binary where one is either married or not. It does not provide any insight into what can be expected when a person is separated or divorced, and simply assumes that all single persons can be grouped together. This theory also tells nothing of the dynamics of when a person is living with a partner, but they are not legally married.

\section{Data and methodology}

The data used for this article were acquired from the National Income Dynamics Survey (NIDS 2016). National Income Dynamics Survey is a nationally representative individual and household survey that collects data of approximately 28000 individuals and 7300 households. The same individuals are interviewed for each of the four waves of the survey, all four of which are used as a panel in this study. The four waves cover the years 2008, 2010, 2012 and 2014. Observations with missing variables were dropped, leaving a sample of 12897 observations.

'Employed' includes only those people who are working for a wage. The study was conducted in sections with a panel logistic model that progressed through various stages. In the first logistic model, gender was included as a dummy variable so that the difference between the genders can be seen, in general. In the next model, the genders were split up into two separate regressions to observe the more specific differences in the factors affecting the employment and labour force participation of women and men. In the third model, the effect of having biological children living with the women is included. ${ }^{1}$

Based on the theory and data availability, the following overarching model can be specified:

$$
\begin{aligned}
p r(\mathrm{EMP}= & 1 / X) \\
= & F\left(\beta+\beta_{0} \mathrm{GEN}+\beta_{1} \sum_{j=1}^{3} \mathrm{MST}+\beta_{2} \sum_{j=1}^{4} \mathrm{GRP}\right. \\
& +\beta_{3} \sum_{j=1}^{3} \mathrm{EDS}+\beta_{4} \sum_{j=1}^{4} \mathrm{EDT}+\beta_{5} \sum_{j=1}^{5} \mathrm{AGE} \\
& \left.+\beta_{6} \sum_{j=1}^{9} \mathrm{PROV}+\beta_{7} \mathrm{NEI}+\beta_{8} \mathrm{CHILD}\right)
\end{aligned}
$$

where EMP is the dichotomous dependent variable, indicating employment, where 1 is employed and 0 is not

\footnotetext{
1.Unfortunately, this variable is not available for men, so a comparison of the genders is not possible.
}

employed; $X$ is a vector of explanatory variables; $j$ is the number of dummies; GEN is the dichotomous variable, indicating gender, where 1 is male and 0 is female; MST is a set of dichotomous variables, indicating marital status with the following categories: married, divorced, widowed, cohabiting and never married; GRP is a set of dichotomous variables, indicating population group, with the following categories: black-, mixed race-, Asian- and white people; EDS is a set of dichotomous variables, indicating education at school level, with the following categories: matric, some schooling and no schooling; EDT is a set of dichotomous variables, indicating education at tertiary level, with the following categories: bachelor's degree, honours degree, master's and doctoral degrees and other tertiary education; AGE is a set of dichotomous variables, indicating age, with the following categories: $15-25,26-35,36-45,46-55$ and 56-65; PROV is a set of dichotomous variables, indicating province of residence, with the following categories: Gauteng, Western Cape, Eastern Cape, Northern Cape Free State, KwaZulu-Natal, North-West, Mpumalanga and Limpopo; NEI is a dichotomous variable, indicating non-employment income, where 1 is receiving NEI and 0 is not receiving NEI and CHILD is the dichotomous variable, indicating the presence of biological children living in the house, where 1 is that there is a biological child living in the house and 0 is that there is not a biological child living in the house.

The employment dependent variable (EMP) was derived from the following question in the NIDS survey (NIDS 2016):

Are you currently being paid a wage or salary to work on a regular basis for an employer (that is not yourself) whether full time or part time?

More specifications of each model will be given in the discussion of each model's result, below.

\section{Results}

The following tables provide some summary statistics of the data being used, hinting towards what could be expected from the models. To ensure that the data remain nationally representative, weightings provided by NIDS (2016) were used. Because all of the variables are dummies, the means can be interpreted as percentages for which the dummy is equal to 1 . Table 1 shows the summary statistics for the year 2014. From Table 1, it is evident that $45.5 \%$ of the respondents are working for a wage. The majority of respondents have either never married or are currently married: $49.1 \%$ and $34.6 \%$, respectively. In 2014, all respondents received some form of NEI, which may present some difficulties when the model is run, attributable to there being not enough difference between the groups analysed.

Table 2 is a cross-tabulation of the employed dummy and the gender dummy. From Table 2, a picture of the situation that women in general face in the labour force can be seen. Of all those who are not employed in the sample, $67.9 \%$ 
TABLE 1: Summary statistics for 2014.

\begin{tabular}{|c|c|c|}
\hline Variable & Mean & Standard deviation \\
\hline Employed & 0.455 & 0.498 \\
\hline Male dummy & 0.430 & 0.495 \\
\hline Married & 0.346 & 0.476 \\
\hline Divorced & 0.036 & 0.187 \\
\hline Widow & 0.064 & 0.245 \\
\hline Cohabit & 0.062 & 0.241 \\
\hline Never married & 0.491 & 0.500 \\
\hline Black people & 0.800 & 0.400 \\
\hline Mixed race people & 0.084 & 0.277 \\
\hline Indian people & 0.026 & 0.160 \\
\hline White people & 0.089 & 0.285 \\
\hline Matric & 0.389 & 0.488 \\
\hline No schooling & 0.014 & 0.117 \\
\hline Some schooling & 0.564 & 0.496 \\
\hline Degree & 0.028 & 0.164 \\
\hline Honours & 0.013 & 0.112 \\
\hline Master's and PhD & 0.007 & 0.083 \\
\hline Other tertiary & 0.237 & 0.425 \\
\hline Ages $15-25$ & 0.158 & 0.365 \\
\hline Ages 26-35 & 0.303 & 0.459 \\
\hline Ages 36-45 & 0.232 & 0.422 \\
\hline Ages 46-55 & 0.185 & 0.388 \\
\hline Ages 56-65 & 0.123 & 0.328 \\
\hline Gauteng & 0.290 & 0.454 \\
\hline Western Cape & 0.103 & 0.305 \\
\hline Eastern Cape & 0.121 & 0.327 \\
\hline Northern Cape & 0.027 & 0.162 \\
\hline Free State & 0.054 & 0.227 \\
\hline KwaZulu-Natal & 0.182 & 0.386 \\
\hline North-West & 0.053 & 0.224 \\
\hline Mpumalanga & 0.083 & 0.277 \\
\hline Limpopo & 0.085 & 0.279 \\
\hline Non-employment income & 1.000 & 0.000 \\
\hline Child dummy & 0.418 & 0.493 \\
\hline
\end{tabular}

Source: Authors' own calculation from NIDS 2016

TABLE 2: Employment and gender cross-tabulation for 2014

\begin{tabular}{llccc}
\hline \multirow{2}{*}{ Employment status } & \multicolumn{2}{c}{ Gender } & \multirow{2}{*}{ Total } \\
\cline { 3 - 4 } & & Male & Female & \\
\hline Unemployed & Number of observations & 1832 & 3884 & 5716 \\
& \% within employed & 32.1 & 67.9 & 100.0 \\
& \% within gender & 51.1 & 66.1 & 60.4 \\
& \% of Total & 19.4 & 41.1 & 60.4 \\
Employed & Number of observations & 1753 & 1990 & 3743 \\
& \% within employed & 46.8 & 53.2 & 100.0 \\
& \% within gender & 48.9 & 33.9 & 39.6 \\
& \% of total & 18.5 & 21.0 & 39.6 \\
Total & Number of observations & 3585 & 5874 & 9459 \\
& \% within employed & 37.9 & 62.1 & 100.0 \\
& \% within gender & 100.0 & 100.0 & 100.0 \\
& \% of Total & 37.9 & 62.1 & 100.0 \\
Chi-squared test Asymptotic Significance & \multicolumn{2}{c}{0.000} & - \\
(two-sided) & & & & \\
\hline
\end{tabular}

Source: Authors' own calculation from NIDS (2016)

were women in 2014. Women also make up 53.2\% of the employed population, which is a majority, but seeing as they make up $62.92 \%$ of the entire sample, this figure is actually quite low. The chi-squared test shows that there is good model fit between gender and employment, and therefore that there is some linear relationship between the two variables.
Table 3 is a cross-tabulation of employment and marital status. Only the widowed and the never married dummies had a lower portion of employed people than the sample average. Of all of the divorced people in the sample, $46.78 \%$ are employed, which is the largest of any of the marital statuses.

The panel tabulation for employment in Table 4 shows $31.94 \%$ of all (person-year) observations are employed. It will be seen that $54.72 \%$ of all individuals had been employed at some stage between the years 2008 and 2014, for which the surveys were conducted. The total of the Between column shows that $140.8 \%$ of the individuals were either employed or unemployed. This means that $40.8 \%$ of the sample either made a transition from employed to unemployed, or the other way around. The Within column further confirms that there is considerable time variance for the employed variable.

The employment transition matrix for employment in Table 5 indicates the probability that an individual will transition from, or to, employment in the following year. There is a $26.16 \%$ chance that an individual who is currently employed will not have a job in the next year. There is, however, only a $16.74 \%$ chance that an individual who does not currently have employment will be employed in the following year.

Now that a rough understanding of the data has been overviewed, the model results will be dealt with. The results are presented below for the employment models (Table 6). Thereafter, analysis of the results will be presented for each model separately.

\section{Employment model 1 (Table 6)}

According to the model, women have a 53.1\% lower probability of being employed in South Africa than men do. The rest of the this model only shows what traits influence a person's probability of being employed, without showing how these traits differently affect women and men. It does, however, provide an indication of the general trends caused by these characteristics in the country.

\section{Employment model 2 (Table 6)}

The analysis of this section is derived from the second column in Table 6. From the high odds ratios for all the marital statuses for women, it is made clear that women are least likely to be employed if they are married. Women are most likely to be employed if they are divorced or if they have never been married, $92.7 \%$ and $33.2 \%$ more probable, respectively, than when they are married. This means that women are most likely to be employed if they are not living with their partner, married or not. The opposite is true for men. Men are most likely to be employed if they are married or living with a partner. They have a $63.6 \%$ lower probability of being employed if they have never been married. 
TABLE 3: Employed and marital status cross-tabulation for 2014.

\begin{tabular}{|c|c|c|c|c|c|c|c|c|c|c|c|}
\hline \multicolumn{2}{|c|}{ Employment status } & \multicolumn{2}{|c|}{ Married } & \multicolumn{2}{|c|}{ Cohabit } & \multicolumn{2}{|c|}{ Widowed } & \multicolumn{2}{|c|}{ Divorced } & \multicolumn{2}{|c|}{ Never married } \\
\hline & & No & Yes & No & Yes & No & Yes & No & Yes & No & Yes \\
\hline \multirow[t]{4}{*}{ Unemployed } & Number of observations & 4078 & 1638 & 5276 & 440 & 5157 & 559 & 5562 & 154 & 2794 & 2922 \\
\hline & $\%$ within Employed & 71.3 & 28.7 & 92.3 & 7.7 & 90.2 & 9.8 & 97.3 & 2.7 & 48.9 & 51.1 \\
\hline & $\%$ within Marital status & 61.2 & 58.5 & 60.6 & 58.0 & 59.2 & 74.2 & 60.7 & 52.0 & 60.6 & 60.3 \\
\hline & $\%$ of Total & 43.1 & 17.3 & 55.8 & 4.7 & 54.5 & 5.9 & 58.8 & 1.6 & 29.5 & 30.9 \\
\hline \multirow[t]{4}{*}{ Employed } & Number of observations & 2581 & 1162 & 3425 & 318 & 3549 & 194 & 3601 & 142 & 1817 & 1926 \\
\hline & $\%$ within Employed & 69.0 & 31.0 & 91.5 & 8.5 & 94.8 & 5.2 & 96.2 & 3.8 & 48.5 & 51.5 \\
\hline & $\%$ within Marital status & 38.8 & 41.5 & 39.4 & 42.0 & 40.8 & 25.8 & 39.3 & 48.0 & 39.4 & 39.7 \\
\hline & $\%$ of Total & 27.3 & 12.3 & 36.2 & 3.4 & 37.5 & 2.1 & 38.1 & 1.5 & 19.2 & 20.4 \\
\hline \multirow[t]{4}{*}{ Total } & Number of observations & 6659 & 2800 & 8701 & 758 & 8706 & 753 & 9163 & 296 & 4611 & 4848 \\
\hline & \% within Employed & 70.4 & 29.6 & 92.0 & 8.0 & 92.0 & 8.0 & 96.9 & 3.1 & 48.7 & 51.3 \\
\hline & $\%$ within Marital status & 100.0 & 100.0 & 100.0 & 100.0 & 100.0 & 100.0 & 100.0 & 100.0 & 100.0 & 100.0 \\
\hline & $\%$ of Total & 70.4 & 29.6 & 92.0 & 8.0 & 92.0 & 8.0 & 96.9 & 3.1 & 48.7 & 51.3 \\
\hline \multicolumn{2}{|c|}{$\begin{array}{l}\text { Chi-squared test Asymptotic Significance } \\
\text { (two-sided) }\end{array}$} & 0.013 & & 0.162 & & 0.000 & & 0.003 & & 0.749 & \\
\hline
\end{tabular}

Source: Authors' own calculation from NIDS (2016)

TABLE 4: Employment panel tabulation.

\begin{tabular}{|c|c|c|c|c|c|}
\hline \multirow[t]{2}{*}{ Employment status } & \multicolumn{2}{|c|}{ Overall } & \multicolumn{2}{|c|}{ Between } & \multirow{2}{*}{$\begin{array}{c}\text { Within } \\
(\%)\end{array}$} \\
\hline & Frequency & $\%$ & Frequency & $\%$ & \\
\hline Unemployed & 23678 & 68.06 & 8188 & 86.08 & 78.88 \\
\hline Employed & 11110 & 31.94 & 5205 & 54.72 & 58.66 \\
\hline Total & 34788 & 100 & 13393 & 140.8 & 71.02 \\
\hline
\end{tabular}

Source: Authors' own calculation from NIDS (2016)

$n=9512$.

TABLE 5: Employment transition matrix.

\begin{tabular}{lccc}
\hline Current employment status & \multicolumn{2}{c}{ Employment status in one year } & Employed \\
\cline { 2 - 4 } & Unemployed & 16.74 & 100 \\
\hline Unemployed & 83.26 & 73.84 & 100 \\
\hline Employed & 26.16 & $\mathbf{3 3 . 4 3}$ & $\mathbf{1 0 0}$ \\
\hline
\end{tabular}

Source: Authors' own calculation from NIDS (2016)

TABLE 6: Employment logistic regression results.

\begin{tabular}{|c|c|c|c|c|c|c|c|c|}
\hline \multirow[t]{3}{*}{ Characteristics } & \multicolumn{2}{|c|}{ Model 1} & \multicolumn{4}{|c|}{ Model 2} & \multicolumn{2}{|c|}{ Model 3: Woman } \\
\hline & \multirow[t]{2}{*}{ Odds ratio } & \multirow[t]{2}{*}{ S.D. } & \multicolumn{2}{|c|}{ Odds ratio } & \multicolumn{2}{|c|}{ S.D. } & \multirow[t]{2}{*}{ Odds ratio } & \multirow[t]{2}{*}{ S.D. } \\
\hline & & & Men & Woman & Men & Woman & & \\
\hline Gender & & 0.012 & & & & & & \\
\hline Male $[r]$ & 1.000 & - & - & - & - & - & - & - \\
\hline Female & 0.469 & - & - & - & - & - & - & - \\
\hline \multicolumn{9}{|l|}{ Marital status } \\
\hline Married $[r]$ & 1.000 & - & 1.000 & 1.000 & - & - & 1.000 & - \\
\hline Divorced & 1.435 & $0.109 * * *$ & 0.778 & 1.927 & $0.112 *$ & $0.174 * * *$ & 1.898 & $0.172 * * *$ \\
\hline Widowed & 1.085 & 0.065 & 0.724 & 1.307 & $0.118^{* *}$ & $0.088 * * *$ & 1.304 & $0.088 * * *$ \\
\hline Cohabit & 1.057 & 0.052 & 0.836 & 1.103 & $0.065^{* *}$ & 0.075 & 1.085 & 0.073 \\
\hline Never married & 0.869 & $0.030 * * *$ & 0.364 & 1.332 & $0.023 * * *$ & $0.058 * * *$ & 1.302 & $0.057 * * *$ \\
\hline \multicolumn{9}{|l|}{ Population group } \\
\hline Black people $[r]$ & 1.000 & - & 1.000 & 1.000 & - & - & 1.000 & - \\
\hline Mixed race people & 1.598 & $0.080 * * *$ & 1.662 & 1.570 & $0.137 * * *$ & $0.101 * * *$ & 1.587 & $0.102 * * *$ \\
\hline White people & 0.844 & $0.070 * *$ & 0.924 & 0.811 & 0.126 & $0.088^{*}$ & 0.795 & $0.086^{* *}$ \\
\hline \multicolumn{9}{|l|}{ Education } \\
\hline Matric $[r]$ & 1.000 & - & 1.000 & 1.000 & - & - & 1.000 & - \\
\hline No schooling & 0.362 & $0.022 * * *$ & 0.559 & 0.279 & $0.055 * * *$ & $0.023 * * *$ & 0.280 & $0.023 * * *$ \\
\hline Some schooling & 0.483 & $0.015 * * *$ & 0.558 & 0.441 & $0.026 * * *$ & $0.017 * * *$ & 0.445 & $0.018 * * *$ \\
\hline \multicolumn{9}{|l|}{ Tertiary education } \\
\hline Degree $[r]$ & 1.000 & - & 1.000 & 1.000 & - & - & 1.000 & - \\
\hline Honours & 4.240 & $0.938 * * *$ & 3.288 & 4.699 & $1.354 * * *$ & $1.236 * * *$ & 4.772 & $1.255^{* * *}$ \\
\hline Masters and PhD & 2.178 & $0.666 * *$ & 1.773 & 6.608 & $0.612 *$ & $4.70 * * *$ & 6.863 & $4.897 * * *$ \\
\hline Other tertiary education & 1.875 & $0.074 * * *$ & 1.442 & 2.180 & $0.091 * * *$ & $0.110 * * *$ & 2.174 & $0.110 * * *$ \\
\hline
\end{tabular}


TABLE 6 (Continues...): Employment logistic regression results.

\begin{tabular}{|c|c|c|c|c|c|c|c|c|}
\hline \multirow[t]{3}{*}{ Characteristics } & \multicolumn{2}{|c|}{ Model 1} & \multicolumn{4}{|c|}{ Model 2} & \multicolumn{2}{|c|}{ Model 3: Woman } \\
\hline & \multirow[t]{2}{*}{ Odds ratio } & \multirow[t]{2}{*}{ S.D. } & \multicolumn{2}{|c|}{ Odds ratio } & \multicolumn{2}{|c|}{ S.D. } & \multirow[t]{2}{*}{ Odds ratio } & \multirow[t]{2}{*}{ S.D. } \\
\hline & & & Men & Woman & Men & Woman & & \\
\hline \multicolumn{9}{|l|}{ Age } \\
\hline $15-25$ & 0.312 & $0.015 * * *$ & 0.641 & 0.234 & $0.050 * * *$ & $0.015^{* * *}$ & 0.225 & $0.014 * * *$ \\
\hline $26-35$ & 1.038 & 0.043 & 1.971 & 0.812 & $0.142 * * *$ & $0.042 * * *$ & 0.821 & $0.043 * * *$ \\
\hline $36-45$ & 1.341 & 0.052 & 1.735 & 1.235 & $0.117 * * *$ & $0.060 * * *$ & 1.254 & $0.061 * * *$ \\
\hline $46-55[r]$ & 1.000 & - & 1.000 & 1.000 & - & - & 1.000 & - \\
\hline $56-65$ & 0.485 & $0.026 * * *$ & 0.475 & 0.475 & $0.040 * * *$ & $0.032 * * *$ & 0.465 & $0.032 * * *$ \\
\hline \multicolumn{9}{|l|}{ Province } \\
\hline Gauteng $[r]$ & 1.000 & - & 1.000 & 1.000 & - & - & 1.000 & - \\
\hline Western Cape & 0.938 & 0.056 & 0.837 & 0.999 & $0.081 *$ & 0.077 & 1.001 & 0.078 \\
\hline Eastern Cape & 0.447 & $0.023 * * *$ & 0.378 & 0.497 & $0.030 * * *$ & $0.034 * * *$ & 0.498 & $0.034 * * *$ \\
\hline Northern Cape & 0.599 & $0.037 * * *$ & 0.653 & 0.558 & $0.061 * * *$ & $0.046 * * *$ & 0.562 & $0.046 * * *$ \\
\hline Free State & 0.688 & $0.040 * * *$ & 0.628 & 0.741 & $0.056 * * *$ & $0.057 * * *$ & 0.748 & $0.058 * * *$ \\
\hline KwaZulu-Natal & 0.505 & $0.022 * * *$ & 0.433 & 0.544 & $0.029 * * *$ & $0.031 * * *$ & 0.552 & $0.032 * * *$ \\
\hline North-West & 0.576 & $0.033 * * *$ & 0.675 & 0.511 & $0.058 * * *$ & $0.041 * * *$ & 0.520 & $0.042 * * *$ \\
\hline Mpumalanga & 0.698 & $0.039 * * *$ & 0.735 & 0.661 & $0.063 * * *$ & $0.050 * * *$ & 0.669 & $0.050 * * *$ \\
\hline Limpopo & 0.393 & $0.022 * * *$ & 0.317 & 0.452 & $0.028 * * *$ & $0.034 * * *$ & 0.457 & $0.034 * * *$ \\
\hline \multicolumn{9}{|l|}{ Non-employment income } \\
\hline No non-employment income $[r]$ & 1.000 & - & 1.000 & 1.000 & - & - & 1.000 & - \\
\hline Non-employment income & 0.640 & 0.433 & 0.524 & 1.369 & $0.453 * * *$ & 1.664 & 1.420 & 1.717 \\
\hline \multicolumn{9}{|l|}{ Children } \\
\hline Do not have children $[r]$ & - & - & - & - & - & - & 1.000 & - \\
\hline Have children & - & - & - & - & - & - & 0.859 & $0.034 * * *$ \\
\hline Pseudo $R^{2}$ & 0.136 & - & 0.149 & 0.125 & - & - & 0.125 & - \\
\hline Observations & 34784 & - & 12897 & 21887 & - & - & 21887 & - \\
\hline
\end{tabular}

Source: Authors' own calculation from NIDS (2016)

Note: $[r]$ refers to the reference variable in each section.

$*, * *, * * *$, Statistically significant at $0.1,0.05$ and 0.01 , respectively.

For both genders, mixed race people were most likely to be employed (Table 6). Mixed race women have a 57\% higher probability of being employed than black women do. Mixed race men have a $66.2 \%$ higher probability of being employed than black men do. Asian men have a 20.5\% higher probability of being employed than black men do, whereas Asian women have a $16.9 \%$ lower probability of being employed than black women do.

Non-employment income was omitted when the logistic model was run because of near-perfect results (see Table 6). This again means that there was almost no discernible difference between women who received NEI and those who did not. Men showed a higher probability of being employed when receiving NEI than when not receiving it. The NEI variable for men was, however, not statistically significant.

\section{Employment model 3 (Table 6)}

Women who had biological children still living with them were $14.1 \%$ less likely to be employed (Table 6) than women who did not have biological children living with them were. The introduction of the child variable had only a marginal effect on the rest of the variables that were illustrated in model 2. Model 3 shows how children can influence labour market outcomes. The limited availability of the data unfortunately restricts our analysis of the influence of children on employment.

\section{Conclusion}

This study was aimed at providing a deeper understanding of how it is that individual characteristics contribute to employment, especially when it comes to marital status.

The results of the logistic regressions showed that although the probabilities of the two regressions differed, similar patterns were apparent in both. The same characteristics that increased the probability of participating in the labour force also increased the probability of being employed. This is also true for the characteristics that contributed least. There are two reasons that can contribute to this phenomenon. The most obvious of these is that those who are employed are, by definition, also participating in the labour force, and they therefore also significantly contribute to the same results. The other reason for this is that it could be reasonable to assume that people know which characteristics are sought by employers, causing those who satisfy these requirements to be less likely to be discouraged and so continue to look for work.

When men are living with their partner, through either marriage or cohabitation, they were most likely to be employed. The opposite is true for women in that they are least likely to be employed when living with their partner. This should give insight to policy-makers in understanding how differently policies can affect women and men in the labour force. Policies that promote 
cohabitation and marriage, for example, could improve men's labour force behaviour but distort women's participation and employment.

Future research could look into the change of these characteristics over time. Other studies could also do more in-depth analysis of the effects of children in and outside of marriage and the implications on labour force participation. Furthermore, it would be beneficial to undertake more research into the interaction between labour demand and supply, rather than only looking at the one or the other.

\section{Acknowledgements Competing interests}

The authors declare that they have no financial or personal relationships that may have inappropriately influenced them in writing this article.

\section{Authors' contributions}

C.C.J.V.R. synthesised the theoretical foundation of the article and executed the data analysis. C.C. provided guidance and expertise, especially regarding feminist economics and gender studies, and revised and edited the various drafts. A.F. contributed specific insight on alternative methodologies and econometric techniques used in the article, and revised and edited later versions of the article.

\section{Ethical considerations}

This article followed all ethical standards for research without direct contact with human or animal subjects.

\section{Funding}

This research received no specific grant from any funding agency in the public, commercial or not-for-profit sectors.

\section{Data availability statement}

Data sharing is not applicable to this article as no new data were created or analysed in this study.

\section{Disclaimer}

The views and opinions expressed in this article are those of the authors and do not necessarily reflect the official policy or position of any affiliated agency of the authors.

\section{References}

Agénor, P.R. \& Canuto, O., 2015, 'Gender equality and economic growth in Brazil: A long-run analysis', Journal of Macroeconomics 43, 155-172. https://doi. org/10.1016/j.jmacro.2014.10.004

Barker, F., 2015, The South African labour market theory and practice, 5th edn., Van Schaik Publishers, Pretoria.

Becker, G.S., 1965, 'A theory of the allocation of time', The Economic Journal 75(299), 493-517. https://doi.org/10.2307/2228949
Becker, G.S., 1993, Human capital: A theoretical and empirical analysis, with special reference to education, 3rd edn., University of Chicago, Chicago, IL.

Berger, F., Islam, N. \& Liegeois, P., 2011, 'Behavioural microsimulation and female labour supply in Luxembourg', Brussels Economic Review 54(4), 389-420.

Bhorat, H., 2003, The post-apartheid challenge: Labour demand trends in the South African labour market, 1995-1999, Development Policy Research Unit Working Paper 03/82, University of Cape Town, Cape Town.

Borck, R., 2014, 'Adieu Rabenmutter: Culture, fertility, female labour supply, the gender wage gap and childcare', Journal of Population Economics 27(1), 739-765. https://doi.org/10.1007/s00148-013-0499-z

Bredemeier, C. \& Juessen, F., 2013, 'Assortative mating and female labor supply', Journal of Labor Economics 31(3), 603-631. https://doi.org/10.1086/ 669820

Burger, R. \& Jafta, R., 2006, 'Returns to race: Labour market discrimination in postApartheid South Africa', Working Paper, Department of Economics, Stellenbosch University, Stellenbosch.

Casale, D. \& Posel, D., 2013, 'The relationship between sex ratios and marriage rates in South Africa', Applied Economics 45(5), 663-676. https://doi.org/10.1080/000 36846.2011.610749

Casale, D., Posel, D. \& Rudwick, S., 2011, 'Is marriage a dying institution in South Africa? Exploring changes in marriage in the context of ilobolo payments', Agenda 25(1) 102-111. https://doi.org/10.1080/10130950.2011.575589

Chen, J., Murtaza, G., Shao, X. \& Zhao, Z., 2014, 'Factors that influence female labour force supply in China', Economic Modelling 37, 485-491. https://doi. org/10.1016/j.econmod.2013.11.043

Coleman, M. \& Pencavel, J., 1993, 'Trends in market work behavior of women since 1940', Industrial and Labor Relations Review 46(4), 653-676. https://doi. org/10.1177/001979399304600405

Collet, R. \& Legros, D., 2016, 'Dynamics of female labour force participation in France', Applied Economics 48(30), 2807-2821. https://doi.org/10.1080/00036846.2015.1 130787

Dias, R. \& Posel, D., 2007, Unemployment, education and skills constraints in postapartheid South Africa, Development Policy Research Unit Working Paper 07/120 University of KwaZulu-Natal, Durban.

Dollar, D. \& Gatti, R., 1999, Gender inequality, income, and growth: Are good times good for women?, Policy Research Report on Gender and Development Working Paper Series, 1, World Bank, Washington, DC.

Forbes, K.J., 2000, 'A reassessment of the relationship between inequality and growth', The American Economic Review 90(4), 869-887. https://doi.org/10.1257/ aer.90.4.869

Grossbard-Schechtman, S.A. \& Neuman, S., 1988, 'Women's labor supply and marital choice', Journal of Political Economy 96(6), 1294-1302. https://doi.org/ $10.1086 / 261588$

Hamid, S., 1991, 'Determinants of the supply of women in the labour market: A micro analysis', The Pakistan Development Review 30(4), 755-766. https://doi.org/ 10.30541/v30i4IIpp.755-766

Hardoy, I. \& Schone, P., 2015, 'Enticing even higher female labour supply: The impact of cheaper day care', Review of Economics of the Household 13(4), 815-836. https://doi.org/10.1007/s11150-013-9215-8

Hosegood, V., McGrath, N. \& Moultrie, T., 2009, 'Dispensing with marriage: Marital and partnership trends in Rural KwaZulu-Natal, South Africa 2000-2006', Demographic Research 20(13), 279-312. https://doi.org/10.4054/DemRes.2009.20.13

Kingdon, G.G. \& Knight, J., 2004, 'Race and the incidence of unemployment in South Africa', Review of Development in South Africa 8(2), 198-222. https://doi. org/10.1111/j.1467-9361.2004.00228.x

Klasen, S., 1999 , Does gender inequality reduce growth and development? Evidence from Cross-Country Regressions, Policy Research Report on Gender and Development Working Paper Series 7, World Bank, Washington, DC

Klasen, S. \& Lamanna, F., 2009, 'The impact of gender inequality in education and employment on economic growth: New evidence for a panel of countries', Feminist Economics 15(3), 91-132. https://doi.org/10.1080/13545700902893106

Mehra, R. \& Gammage, S., 1999, 'Trends, countertrends, and gaps in women's employment', World Development 27(3), 533-550. https://doi.org/10.1016/ S0305-750X(98)00148-X

Moore, E. \& Govender, R., 2013 'Marriage and cohabitation in South Africa: An enriching explanation?', Journal of Comparative Family Studies 44(5), 623-639. https://doi.org/10.3138/jcfs.44.5.623

Mkhizwe, N., 2006, 'African traditions and the social, economic and moral dimensions of fatherhood', in L. Richter \& R. Morrell (eds.), Baba: Men and fatherhood in South Africa, pp. 183-198, HSRC Press, Cape Town.

Muller, C. \& Posel, D., 2008, 'Is there evidence of a wage penalty to female part-time employment in South Africa?', South African Journal of Economics 76(3), 467-479.

NIDS, 2016, National income dynamics study waves 1-4, Dataset, Southern Africa Labour and Development Research Unit, DataFirst, Cape Town.

Ntuli, M., 2007a, Determinants of South African women's labour force participation, 1995-2004, IZA Discussion paper no. 3119.

Ntuli, M., 2007b, Exploring gender wage 'discrimination' in South Africa, 1995-2004 A quantitative regression approach, IPC Working Paper Series no. 56, University of Michigan, Ann Arbor, Ml. 
Posel, D. \& Casale, D., 2013, 'The relationship between sex ratios and marriage rates in South Africa', Applied Economics 45(5), 663-676. https://doi.org/10.1080/000 in South Africa, App
36846.2011 .610749

Posel, D., Rudwick, S. \& Casale, D., 2011, 'Is marriage a dying institution in South Africa? Exploring changes in marriage in the context of ilobolo payments', Agenda 25(1), 102-111. https://doi.org/10.1080/10130950.2011.575589

Posel, D. \& Rudwick, S., 2013, 'Changing patterns of marriage and cohabitation in South Africa', Acta Juridica 2013(1):169-180.

Posel, D. \& Rudwick, S., 2015, 'Zulu Bridewealth (ilobolo) and womanhood in South Africa', Social Dynamics 41(2), 289-306. https://doi.org/10.1080/025339 52.2015.1060683
Palamuleni, M.E., 2010, 'Recent patterns in South Africa 1996-2007', Bangladesh e-Journal of Sociology 7(1), 47-70.

Seguino, S., 2000, 'Gender inequality and economic growth: A cross-country analysis', World Development 28(7), 1211-1230. https://doi.org/10.1016/S0305-750X(00) 00018-8

Wamboye, E.F., Adekola, A.F. \& Sergi, B.S., 2015, 'Sectoral shifts and women's employment: A study of thirty-nine least developed countries', Journal of Economic Issues 49(4), 1045-1076. https://doi.org/10.1080/00213624.2015.1105039

Yakubu, Y.A., 2010, 'Factors influencing female labor force participation in South Africa', The African Statistical Journal 11, 85-104. 